\title{
Model Development and Transient Seasonal Performance Analysis of a Solar Space Heating System under Climate Conditions of PAKISTAN ${ }^{+}$
}

\author{
Muhammad Arsalan, Muzaffar Ali *(D) and Rubeena Kousar
}

Citation: Arsalan, M.; Ali, M.; Kousar, R. Model Development and Transient Seasonal Performance Analysis of a Solar Space Heating System under Climate Conditions of PAKISTAN. Eng. Proc. 2022, 12, 84. https://doi.org/10.3390/ engproc2021012084

Academic Editor: Shahid Iqbal

Published: 18 January 2022

Publisher's Note: MDPI stays neutral with regard to jurisdictional claims in published maps and institutional affiliations.

Copyright: (C) 2022 by the authors. Licensee MDPI, Basel, Switzerland. This article is an open access article distributed under the terms and conditions of the Creative Commons Attribution (CC BY) license (https:// creativecommons.org/licenses/by/ $4.0 /)$.

\author{
Mechanical Engineering Department, University of Engineering and Technology, Taxila 47080, Pakistan; \\ arsalanstar8901@gmail.com (M.A.); rubeena.kamal.rk@gmail.com (R.K.) \\ * Correspondence: muzaffar.ali@uettaxila.edu.pk \\ + Presented at the 1st International Conference on Energy, Power and Environment, Gujrat, Pakistan, \\ 11-12 November 2021.
}

\begin{abstract}
The model-based transient system simulation approach is very effective for a performance assessment of solar systems under various climate conditions. In the current study, a hybrid array of flat and evacuated tube collector was analyzed for space heating using a panel radiator for a room with a volume of $1600 \mathrm{ft}^{3}$ at different flow rates. A detailed model is developed in TRNSYS that consists of a hybrid collector array, storage tank and pumping device along with a building load component. Using transient simulation, the performance of the hybrid solar space heating system was analyzed from December to February for the subtropical climate of Taxila, Pakistan. The results revealed that at flow rates of 350,450 and $550 \mathrm{~kg} / \mathrm{h}$, the range of temperature gain of the hybrid collector array vary from 2.8 to $15.4^{\circ} \mathrm{C}, 1.7$ to $11.6^{\circ} \mathrm{C}$ and 1.2 to $9.2^{\circ} \mathrm{C}$ from December to February, respectively, whereas the variation in efficiencies are 25.2 to $70.4 \%, 22$ to $70.2 \%$ and 18.4 to $68.1 \%$ for December, January and February, respectively. In addition, it is observed that about 5.29 and $7.97 \%$ better seasonal efficiency is achieved for flow rate $350 \mathrm{~kg} / \mathrm{h}$ as compared to 450 and $550 \mathrm{~kg} / \mathrm{h}$. The resulted room temperature varies from 22.3 to $26.8{ }^{\circ} \mathrm{C}, 22.2$ to $27{ }^{\circ} \mathrm{C}$ and $22.4{ }^{\circ} \mathrm{C}$ to $30{ }^{\circ} \mathrm{C}$ for December, January and February to ensure desired thermal comfort. Overall, the results show that solar heating systems are viable to achieve the thermal comfort in winter and thus can significantly reduce gas consumption in the country.
\end{abstract}

Keywords: transient simulation; TRNSYS; flat plate and evacuated tube collector; space heating

\section{Introduction}

Due to the depletion of fossil fuels and the conventional sources of energy, solar energy can play a vital role [1]. The estimated solar potential of Pakistan is around 2,900,000 MW [2]. Photo-voltaic and thermal technologies are used to harness solar energy [3] in which different types of collectors are used. Simulation results are more precise and advantageous as compared to analytical methods, mainly for the annual analysis of system [4]. The main advantage of simulation is that it is a cost effective and time saving approach for the designing of new systems [5]. The simulation results reveal that an evacuated tube collector (ETC) performs 15 and 30\% better than flat plate collector (FPC) in hot and cold climate [6], respectively. Reportedly, a hybrid array configuration of parabolic trough and flat plate collector causes a reduction of $5-9 \%$ in the investment cost [7]. Similarly, the maximum temperature difference of $12.07^{\circ} \mathrm{C}$ achieved by the hybrid collector and $7^{\circ}$ and $7.71{ }^{\circ} \mathrm{C}$ for FPC, ETC and annual simulation shows $16 \%$ better results by HC than standalone FPC [8].

In view of the above literature, it is concluded that few studies are performed for the utilization of renewable energy for space heating and only a standalone arrangement of collectors are analyzed; therefore, the current study differs from previous studies as (1) an energy analysis of a hybrid array of FPC and ETC is performed, (2) analysis of the 
solar-assisted panel radiator for space heating is performed to achieve thermal comfort for climate conditions of Taxila, Pakistan.

\section{Model Development and Transient Simulations}

In the current study, the hybrid collector (HC) of an absorber area of $12.15 \mathrm{~m}^{2}$ is used for space heating for the subtropical climate of Taxila, Pakistan, in which four FPCs of an absorber area of $7.37 \mathrm{~m}^{2}$ and four ETCs of $4 \mathrm{~m}^{2}$ are connected in series and hot water is supplied through storage tank to the panel radiator. The transient analysis is performed using TRNSYS to analyze the seasonal performance of hybrid solar space heating at three different flow rates of 350, 450 and $550 \mathrm{~kg} / \mathrm{h}$. The intercept efficiency for FPC and ETC is 0.75 and 0.84 , and the stagnation temperatures are 197 and $238^{\circ} \mathrm{C}$ for FPC and ETC, respectively.

\subsection{Model Development}

The transient simulation model is developed using TRNSYS due to its wide applications to analyze the performance of different cooling and heating systems as discussed [4,5]. TRNSYS components are shown in the simulation model in Figure 1.

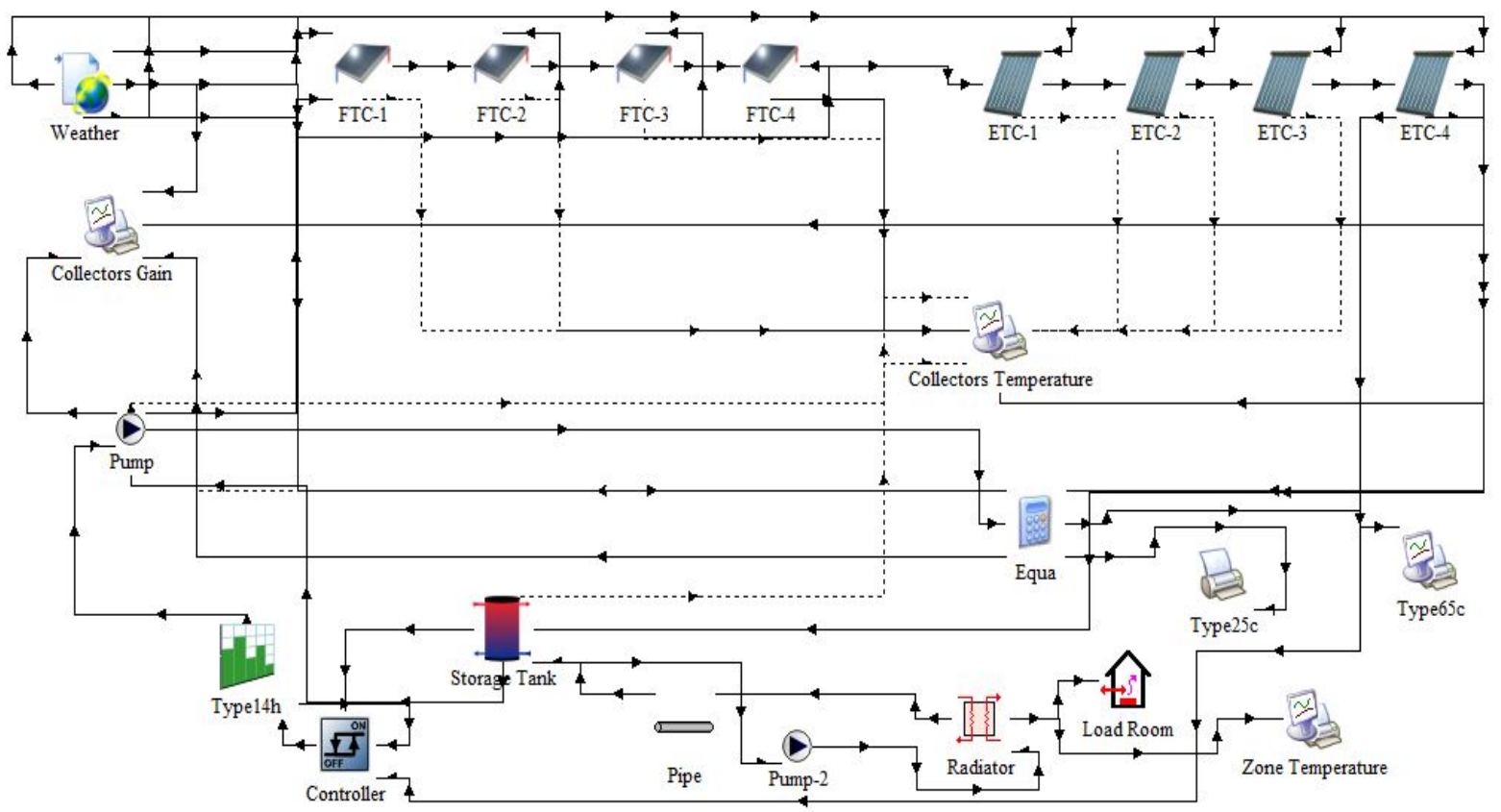

Figure 1. Transient Simulation Model of Hybrid solar space heating system.

\subsection{Working of the System}

Water from the storage tank is pumped through HC and goes back to the storage tank; then hot water is pumped to the panel radiator and heat is transferred by the radiator to room and cold water flows back to the storage tank and the loop continues from 10 a.m. to 5 p.m.

\section{Results and Discussion}

The maximum average values of solar radiation are 539,548 and $730 \mathrm{~W} / \mathrm{m}^{2}$ for December, January and February, respectively, as shown in Figure 2a. Figure 2b shows the thermal gain of $\mathrm{HC}$ in which the maximum value of $6.2 \mathrm{~kW}$ is achieved. 


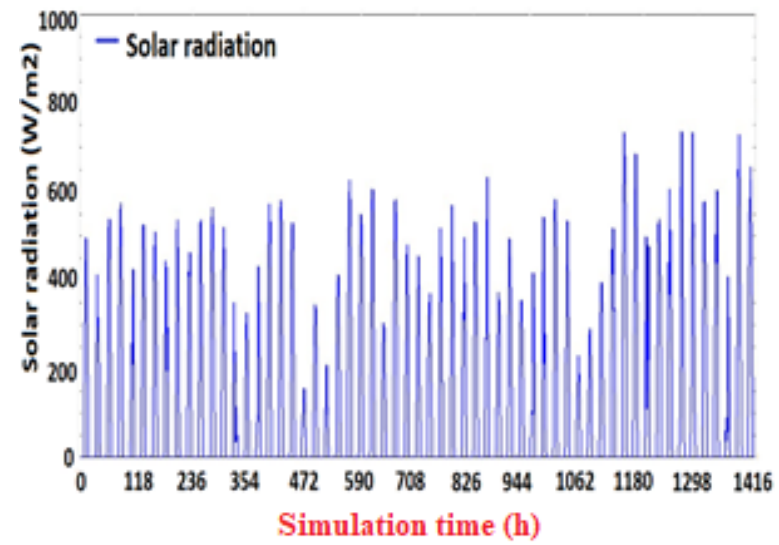

(a)

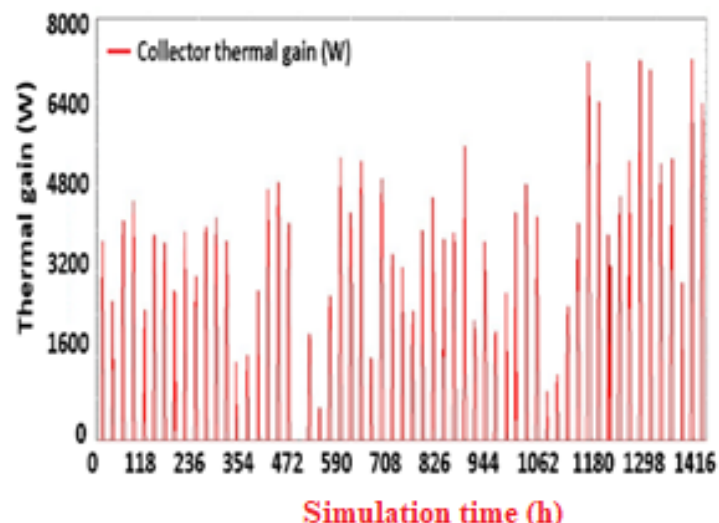

(b)

Figure 2. (a) Variation in Solar Radiation. (b) Effect of flow rate in thermal energy.

Thermal Analysis of Hybrid Solar Collector

The maximum temperature difference and thermal energy gain of collectors are 15.4, 11.6 and $9.2^{\circ} \mathrm{C}$, and $6.2,6$ and $5.8 \mathrm{~kW}$ for the flow rate of 350,450 and $550 \mathrm{~kg} / \mathrm{h}$, respectively, as shown in Figure 3a,b.

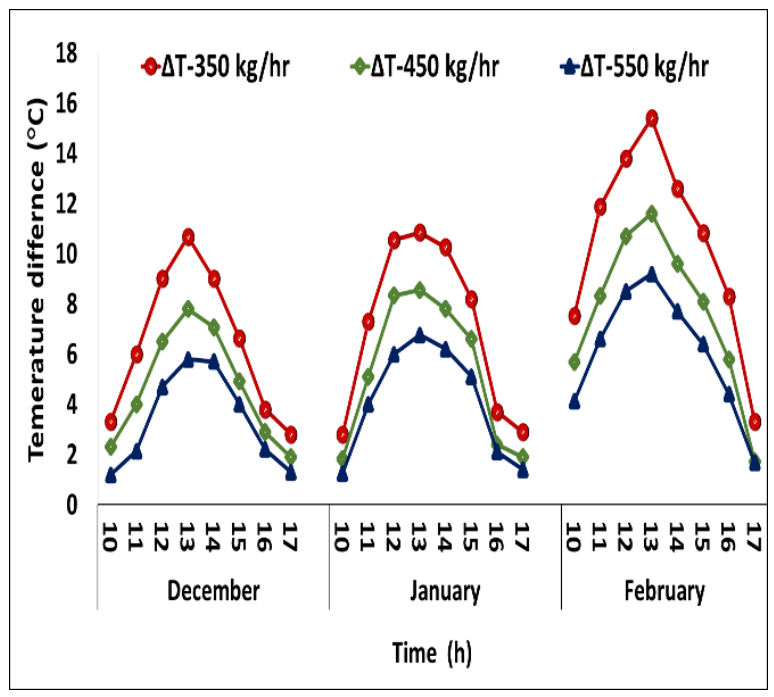

(a)

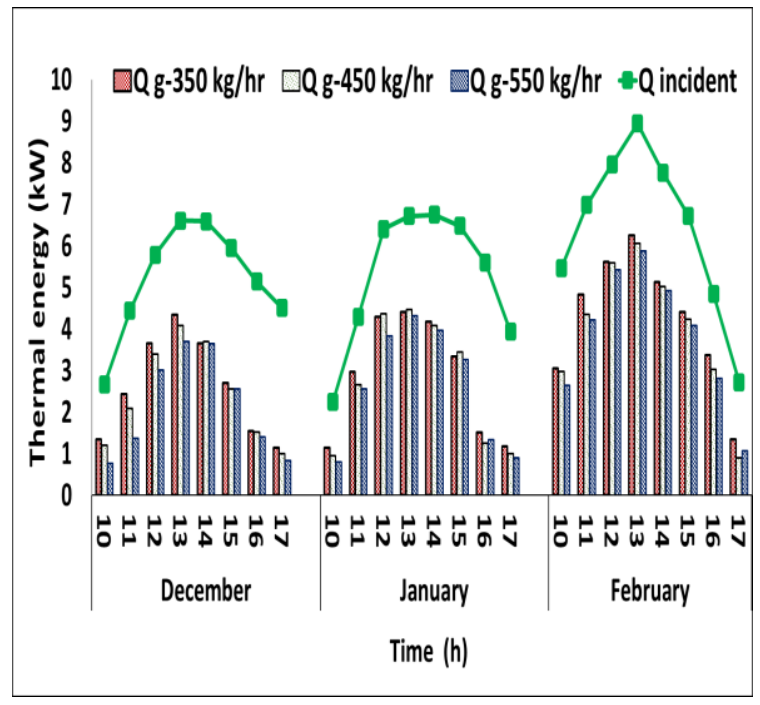

(b)

Figure 3. (a) Variation in temperature difference; (b) Variation in heat gain of solar collector.

The seasonal variation in the efficiency of the $\mathrm{HC}$ with solar radiation is shown in Figure 4a. The maximum value of efficiency for flow rate of 350,450 and $550 \mathrm{~kg} / \mathrm{h}$ are 70,70 and $68 \%$, respectively. The supply air conditions are in shown in Figure $4 \mathrm{~b}$. The maximum values of room temperature are $22.8,27.5$ and $30^{\circ} \mathrm{C}$, respectively, for the flow rates of 350, 450 and $550 \mathrm{~kg} / \mathrm{h}$. 


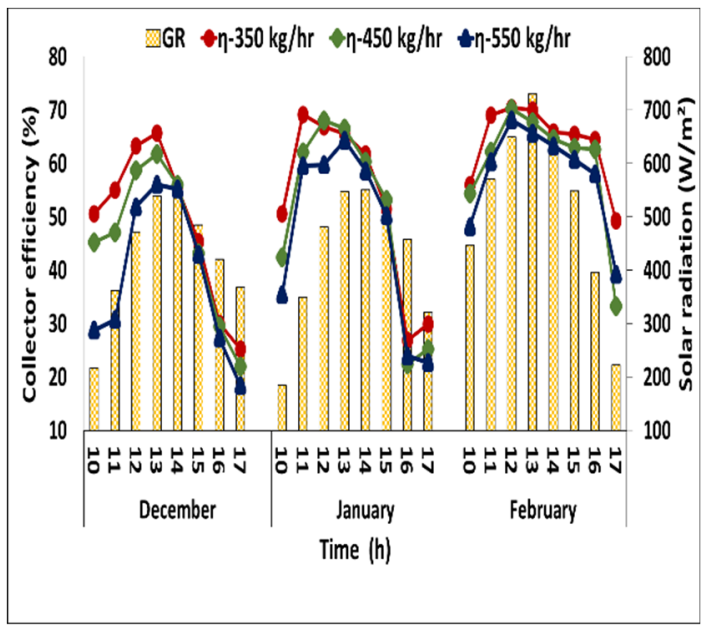

(a)

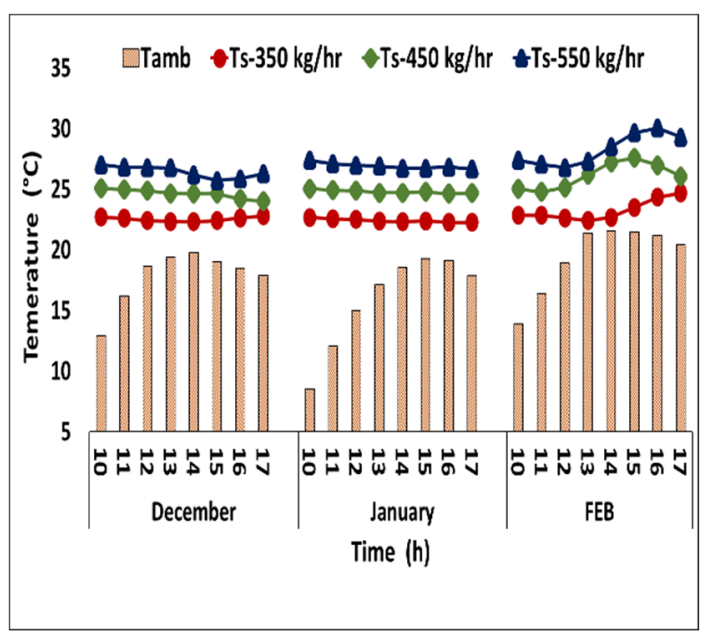

(b)

Figure 4. (a) Thermal efficiency of solar collector; (b) Supply air conditions at different flow rates.

\section{Conclusions}

In the current study, seasonal analysis of hybrid solar space heating was performed from December to February for the subtropical climate of Taxila, Pakistan. The maximum temperature difference of the collector was found to be $15.4^{\circ} \mathrm{C}$ for February. The maximum efficiency for the flow rate of 350 and $450 \mathrm{~kg} / \mathrm{h}$ is $70 \%$, and $68 \%$ for the flow rate of $550 \mathrm{~kg} / \mathrm{h}$. About 5.29 and $7.97 \%$ better seasonal efficiencies were obtained for the flow rate $350 \mathrm{~kg} / \mathrm{h}$ as compared to 450 and $550 \mathrm{~kg} / \mathrm{h}$. The performance of the solar collector was better in February, receiving the highest value of an incident energy of $8.94 \mathrm{~kW}$ and at a mass flow rate of $350 \mathrm{~kg} / \mathrm{h}$. The seasonal variations in room temperature were 22.3 to $26.7^{\circ} \mathrm{C}, 22.2$ to $26.8^{\circ} \mathrm{C}$ and 22.4 to $30^{\circ} \mathrm{C}$ for December, January and February, respectively. In the future, the performance of the hybrid solar space heating system can be predicted for multiple climates of Pakistan.

Institutional Review Board Statement: Not applicable.

Informed Consent Statement: Not applicable.

Data Availability Statement: Not applicable.

Acknowledgments: All Authors are thankful to HEC Pakistan for funding under the program of Technology development fund "TDF 03-337".

\section{References}

1. Abas, N.; Kalair, A.; Khan, N. Review of fossil fuels and future energy technologies. Futures 2015, 69, 31-49. [CrossRef]

2. Wakeel, M.; Chen, B.; Jahangir, S. Overview of energy portfolio in Pakistan. Energy Procedia 2016, 88, 71-75. [CrossRef]

3. Tiwari, G.; Tiwari, A. Handbook of Solar Energy; Springer: Berlin/Heidelberg, Germany, 2016.

4. Lebar, A.; Dillon, H.E. Performance and Optimization of a Small Hybrid Solar-Thermal Collector. Smart Grid Renew. Energy 2018, 9, 259-271.

5. Ali, M.; Sahir, M.H. Optimization of Heating, Ventilation, and Air-Conditioning (HVAC) System Configurations. Ph.D. Thesis, University of Engineering \& Technology, Taxila, Pakistan, 2013.

6. Mohasseb, S.; Kasaeian, A. Comparing the Performance of Flat Plate Collector and Evacuated Tube Collector for Building and Industrial Usage in Hot and Cold Climate in Iran with TRNSYS Software. In Proceedings of the Ninth International Conference on Engineering Computational Technology, Napoli, Italy, 2-5 September 2014.

7. Tian, Z.; Perers, B.; Furbo, S.; Fan, J. Thermo-economic optimization of a hybrid solar district heating plant with flat plate collectors and parabolic trough collectors in series. Energy Convers. Manag. 2018, 165, 92-101. [CrossRef]

8. Kousar, R.; Ali, M. Annual transient simulations and experimental investigation of a hybrid flat plate and evacuated tube collectors array in subtropical climate. Therm. Sci. 2020, 24, 1435-1443. [CrossRef] 